\title{
Extension of the growing season of phytoplankton in the western Baltic Sea in response to climate change
}

\author{
Norbert Wasmund* , Günther Nausch, Monika Gerth, Susanne Busch, \\ Christian Burmeister, Regina Hansen, Birgit Sadkowiak
}

Leibniz Institute for Baltic Sea Research, Seestr. 15, 18119 Rostock-Warnemünde, Germany

ABSTRACT: Phenology of phytoplankton was investigated at a coastal station in the western Baltic Sea from 1988 to 2017 by means of microscopically determined biomass and chlorophyll a (chl a) data. The prolongation of the growing season in this marine area is much stronger than that known from terrestrial areas. The growing season, defined by biomass or chl a thresholds, increased by 125 or 129 d, respectively, and extends recently from February to December. The spring bloom started earlier at a rate of $1.4 \mathrm{~d} \mathrm{yr}^{-1}$ and the end of the autumn bloom was delayed by $3.1 \mathrm{~d}$ $\mathrm{yr}^{-1}$. The duration of the growing season increased at a rate of $4.5 \mathrm{~d} \mathrm{yr}^{-1}$. The earlier start of the growing season was correlated with a slight increase in sunshine duration during spring, whereas the later end of the growing season was correlated with a strong increase in water temperature in autumn. The period with sea surface temperature $>10^{\circ} \mathrm{C}$ shifted towards the end of November. Correlations of the duration of the growing season with the phosphate and nitrate concentrations were probably not causative. The shifts in the spring and autumn blooms led to a prolongation of the summer biomass minimum. The earlier spring bloom was caused, among other factors, by a shift of the biomass maximum of the dominant diatom Skeletonema marinoi from May to February/March. The delay in the autumn bloom was induced by a retardation of dominant dinoflagellates and diatoms, such as Ceratium spp. and Dactyliosolen fragilissimus.

KEY WORDS: Phenology · Seasonality · Longterm changes - Climate change - Phytoplankton · Chlorophyll $\cdot$ Temperature $\cdot$ Nutrients $\cdot$ Baltic Sea

${ }^{*}$ Corresponding author:

norbert.wasmund@io-warnemuende.de

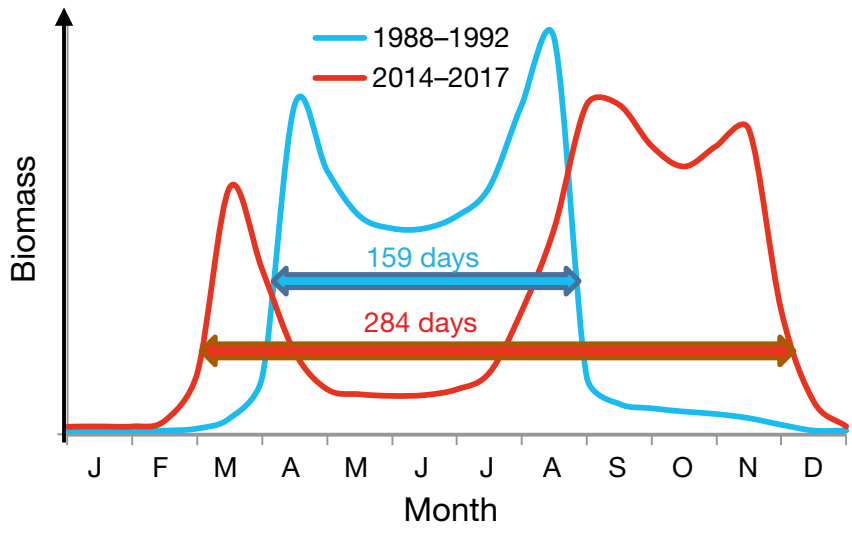

In a 29-yr study, an extended phytoplankton growing season has been observed in the western Baltic Sea.

Image: The authors

\section{INTRODUCTION}

Coastal seas and oceans with all their organisms are a vital resource for the growing human population. Climate change and other anthropogenic pressures endanger these ecosystems, and make management measures essential (Reusch et al. 2018). As a precondition, scientific analysis of the status of these ecosystems, and ongoing changes within them, are necessary. It is common knowledge that anthropogenic input of carbon dioxide and other greenhouse gases is leading to a worldwide climate change (IPCC 2014). A doubling of the atmospheric $\mathrm{CO}_{2}$ concentration and a global ocean surface tem-

() The authors 2019. Open Access under Creative Commons by Attribution Licence. Use, distribution and reproduction are unrestricted. Authors and original publication must be credited. 
perature rise of 2 to $4.5^{\circ} \mathrm{C}$ have been predicted for the 21st century (IPCC 2014).

The resulting effects on ecosystems have received increasing attention in studies of terrestrial systems (e.g. Ibáñez et al. 2010, Cleland et al. 2012, Richardson et al. 2013), but reports of the impacts of climate change in marine ecosystems have been underrepresented in comparison with terrestrial studies, as shown in the compilations by Parmesan \& Yohe (2003) and Rosenzweig et al. (2008). Within marine ecosystems, the majority of climate-related studies have been on zooplankton, fish and sea birds, and only rarely on phytoplankton (see Sydeman \& Bograd 2009 and references within).

Global warming provokes the establishment of invading species, changes in productivity, shifts in species succession and, finally, changes in the food web structure (Nehring 1998, Nixon et al. 2009, Hallegraeff 2010, Smith et al. 2010). The food web structure may be altered because increased temperature enhances heterotrophic processes more strongly than autotrophic processes, and may enhance consumer biomass relative to producer biomass despite increases in primary productivity (O'Connor et al. 2009, Sommer \& Lewandowska 2011). A much more important factor is the shift in bloom timing. An earlier phytoplankton spring bloom may lead to a mismatch with consumers if they are not habituated to the change and therefore not able to feed on this unexpected bloom (Edwards \& Richardson 2004, Sommer et al. 2012a, Thackeray 2012). Earlier spring blooms can be anticipated if accelerated warming in spring leads to earlier stratification (Wasmund et al. 1998). Indeed, Kahru et al. (2016) found a trend of earlier onset of sea surface temperatures (SSTs) $\geq 12^{\circ} \mathrm{C}$ in spring in the Baltic Sea and, therefore, also an earlier increase in spring chlorophyll a (chl a) concentration. Moreover, the end of the high chl a period in the autumn bloom was also delayed. Consequently, the period with a satellite-estimated $\mathrm{chl}$ a concentration $\geq 3 \mathrm{mg}$ $\mathrm{m}^{-3}$ has doubled from approximately $110 \mathrm{~d}$ in 1998 to $220 \mathrm{~d}$ in 2013. Kahru et al. (2016) obtained these data from the central Baltic Sea, excluding the shallow coastal areas.

Effects in coastal areas may be even greater, because impacts of anthropogenic changes are particularly strong along coastlines where human populations are concentrated and where there are considerable influences from terrestrial catchment areas (Cloern et al. 2016). In this study, we concentrate on the potential prolongation of the growing season of phytoplankton at a coastal station in the western Baltic Sea. The duration of the growing season can only be reliably estimated using data series of at least weekly sampling, which cannot be realized by monitoring programmes based on research vessels. However, coastal stations are easily accessible even without ships. For this study, we used coastal monitoring data of the Leibniz Institute of Baltic Sea Research Warnemünde (IOW). This data series is long enough (available from June 1988) to assess long-term changes.

We determined the phytoplankton biomass and the chl a concentration in water samples. We used 'growing season' as a pragmatic technical term to describe the main growth period of the entire phytoplankton biomass. This is the duration between the first and last day that a threshold value is reached, as previously applied by Kahru et al. (2016). The threshold is defined so that the period extends from the start of the spring bloom to the end of the autumn bloom. Similar to terrestrial plant growth, periods of negative net growth which may occur in summer are included in the growing season. The period outside the growing season is more or less restricted to winter when phytoplankton growth is limited primarily by light. This 'resting period' is characterized by permanently low phytoplankton biomass. We must admit that some growth may also occur during this resting period, but this minor growth is excluded from the growing season.

Our hypothesis is that water temperature will have increased and, correspondingly, the growing season of the phytoplankton will have started earlier and extended for longer. We are aware that other factors, such as irradiation, salinity and nutrients may likewise have an influence, and therefore have also taken them into account.

\section{MATERIALS AND METHODS}

\subsection{Study site}

The Baltic Sea is a shallow intra-continental shelf sea with only a narrow connection to the fully marine North Sea. Dense saltwater flows sporadically from the North Sea into the Baltic Sea near the sea bottom, whereas brackish Baltic water flows out at the surface. The Belt Sea, including the Danish Belts, Kiel Bay and the Bay of Mecklenburg, is a highly dynamic system concerning water mass transport. It is separated from the Baltic Proper by the Darss Sill. The Arkona Basin is the westernmost basin of the Baltic Proper. 
The study site is situated at the southern banks of the Bay of Mecklenburg. The time series started on 1 June 1988 with weekly samplings at a pier west of Rostock-Warnemünde $\left(54^{\circ} 11^{\prime} \mathrm{N}, 12^{\circ} 03^{\prime} \mathrm{E}\right)$. The pier was demolished at the end of 1998. To allow continuation of the time series, the sampling position was shifted to the next pier situated $14.5 \mathrm{~km}$ west of the original position at Heiligendamm $\left(54^{\circ} 08.76^{\prime} \mathrm{N}, 11^{\circ} 50.58^{\prime} \mathrm{E}\right)$. The conditions at these 2 positions (Fig. 1) are similar. They are sheltered from the south and exposed to the north. Water depth is 3 to $4 \mathrm{~m}$. The bottom is sandy.

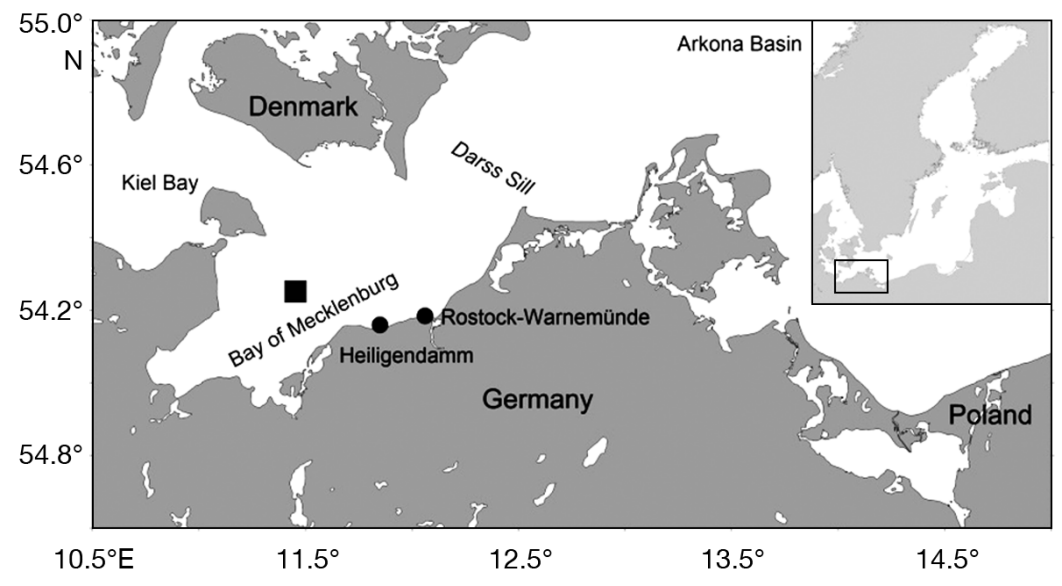

Fig. 1. The locations of the sampling stations in the Bay of Mecklenburg. (घ) SST data collection (provided by NOAA-AVHRR) The average salinity over all data $(\mathrm{n}=$ 1231) is 12.0 with a high variability ranging from 6.6 to 21.1 , depending on the situation of inflowing marine water from the west (Kiel Bay) or outflowing brackish water from the east (Arkona Basin). Tides do not occur, but wind pressure may temporally change the water level at the station.

\subsection{Meteorological variables}

The weather conditions (wind direction, wind speed in Beaufort, cloud cover) were noted down during every sampling. As we have no directly measured data for irradiance from the sampling area, we used the monthly sum of sunshine duration as a proxy. These data were obtained from the Climate Data Center of the Deutscher Wetterdienst (DWD) for the Rostock-Warnemünde Station. The seasonal data are the sum of the monthly values for the seasons as defined in Section 2.8.

Besides the directly measured temperature during sampling, we also made use of the SST data delivered by the German Federal Maritime and Hydrographic Agency (Bundesamt für Seeschifffahrt und Hydrographie, BSH). Values of SST were derived from data of the Advanced Very High Resolution Radiometer (AVHRR) of the National Oceanic and Atmospheric Administration (NOAA) and the European Meteorological Operational Satellite (METOP) in a $3 \times 3$ pixel area in the Bay of Mecklenburg ( $\square$ in Fig. 1). SST in the central Bay of Mecklenburg is more representative for the area than the strongly fluctuating temperature data taken during the sampling, which are subject to dynamical processes like upwelling or diurnal heating in this shallow water.

\subsection{Water sampling}

Surface water samples for phytoplankton and chl a were taken by means of a bucket at about 10:00 h. The water was filled directly into $1000 \mathrm{ml}$ glass bottles for nutrient analysis. During the sampling, water temperature and salinity were measured by means of a TS probe (WTW; Xylem Analytics).

\subsection{Nutrients}

Nutrient samples were filtered through pre-combusted $\left(450^{\circ} \mathrm{C}, 4 \mathrm{~h}\right) \mathrm{GF} / \mathrm{F}$ filters immediately after sampling and stored frozen $\left(-20^{\circ} \mathrm{C}\right)$ until analysis. Inorganic nutrient concentrations (phosphate, nitrite, nitrate, silicate) were measured with standard colorimetric methods (Rohde \& Nehring 1979, Grasshoff et al. 1983) using different autoanalyzer systems (Evolution III and FlowSys; Alliance Instruments).

\subsection{Chl a}

Chl $a$ is a universal plant pigment and can be used as a proxy for phytoplankton biomass. Because of variable conversion factors, a calculation of biomass from chl a concentrations is usually omitted and chl a is taken as a separate variable. We followed the guidelines of the Baltic Marine Environment Protection Commission - Helsinki Commission (HELCOM 1988), which were slightly modified during the course of the study period without noticeable consequences for the analytical results (HELCOM 2017). Accordingly, we shifted from the spectrophotometric 
to the fluorometric method at the beginning of 1995 . From 2003, 96\% ethanol was used as extraction agent instead of $90 \%$ acetone, which allowed homogenization of the filters and centrifugation of the extract to be omitted, as recommended by Wasmund et al. (2006). Up until 2010, the chl a data were corrected for pheopigment $a$ according to the principles of Yentsch \& Menzel (1963) and Lorenzen (1967). In 2010, we also applied the method of Welschmeyer (1994) in parallel analyses. This does not correct the chl a data for pheopigments, but for chl $b$. A large survey conducted in the open sea $(n=653)$ revealed that the data of both methods deviate by only $1 \%$ (Wasmund et al. 2011). Therefore, from 2011 onwards, we used the data analysed with the method of Welschmeyer (1994) without corrections, using a 10AU-005-CE fluorometer (Turner).

\subsection{Phytoplankton biomass}

The quantitative and qualitative analysis of phytoplankton was determined by microscopic counting according to the guidelines for the Baltic Monitoring Programme of HELCOM (HELCOM 1988), which have not changed over the $29 \mathrm{yr}$ that the monitoring programme has been running. Each water sample $(250 \mathrm{ml})$ was preserved with $1 \mathrm{ml}$ acetic Lugol's solution. Sedimentation in combined plate chambers (usually $25 \mathrm{ml}$ ) and the counting of $\geq 500$ objects under an inverted microscope with appropriate magnification $(100 \times, 400 \times)$ were conducted following the principles of Utermöhl (1958). Cell counting and biomass calculations were carried out using the counting programme OrgaCount (AquaEcology), and based on the HELCOM biovolume factors which are annually updated at www.ices.dk/ marine-data/vocabularies/Documents/ PEG_BVOL.zip (for a basic description see Olenina et al. 2006).

\subsection{Definition of the thresholds}

We applied the first 3 phenological indicators used previously by Kahru et al. (2016):

(1) Day of year when a threshold value is first reached (DF: day first)

(2) Day of year when a threshold value is last reached (DL: day last)

(3) Duration between the first and last days on which a threshold value is reached (DD: day duration), which can roughly be considered as the 'growing season'. As we were primarily interested in the extension of the total period, we disregarded the occurrence of sub-periods of low biomass within the growing season.

As these periods are calculated for phytoplankton biomass and chl a independently, they may deviate. Therefore, the specific values for phytoplankton biomass and chl $a$ are marked with the additional letters '-B' and '- $C$ ', respectively.

In order to define the thresholds we had to find the most suitable value to differentiate between the growing season and the resting period. Kahru et al. (2016) adopted a threshold of $3 \mathrm{mg} \mathrm{m}^{-3}$ for nearsurface chl a concentrations derived from satellite images in open Baltic Sea waters. That value could not be applied to our data. In some years (1991, 1997, 2001, 2002, 2003, 2005, 2015), the chl a concentrations in summer and autumn did not even exceed $3 \mathrm{mg} \mathrm{m}^{-3}$, which would make it impossible to identify DL-C. We had to reduce the chl a threshold to $2.3 \mathrm{mg}$ $\mathrm{m}^{-3}$ as a best fitting value. The biomass threshold related to the chl a threshold was derived from the regression curve shown in Fig. 2. This figure compares monthly means of phytoplankton biomass and chl a concentration from October to March of all investigation years up to a biomass level of $1000 \mathrm{mg}$ $\mathrm{m}^{-3}$. These data include the end and the beginning of the growing season (DL, DF) but exclude the highly variable bloom peaks that would disturb the spring and autumn data of interest. According to the regression curve, the chl a value of $2.3 \mathrm{mg} \mathrm{m}^{-3}$ is related to a biomass value of $750 \mathrm{mg} \mathrm{m}^{-3}$, which we adopted as a biomass threshold.

The principle of 'DF', 'DL' and 'DD' was also applied to the ambient water temperature at the sam-

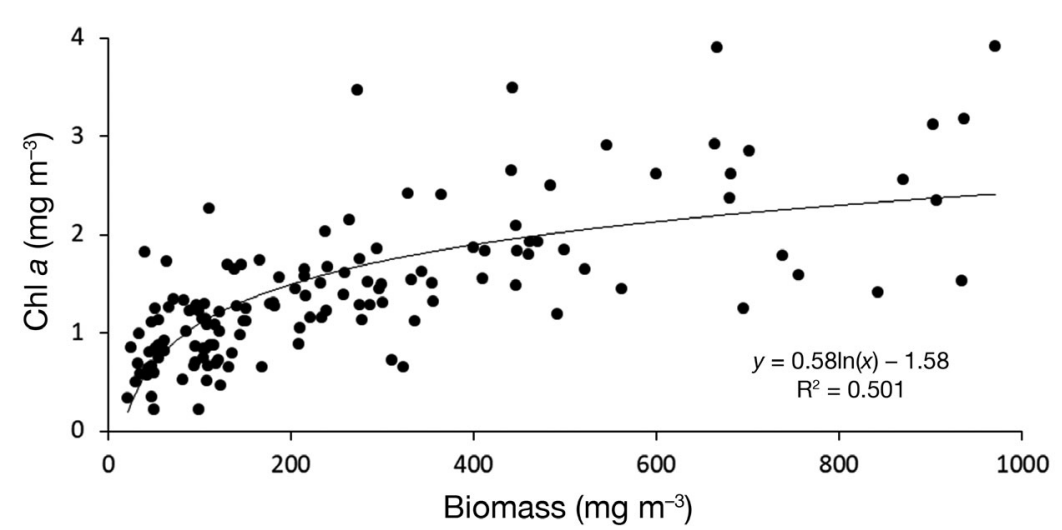

Fig. 2. Relationship between phytoplankton biomass and chl a concentration. Monthly mean values from October to March up to a biomass of $1000 \mathrm{mg} \mathrm{m}^{-3}$ with a logarithmic regression curve 
pling station and SST, using the additional letters ' $-\mathrm{T}$ ' and '-SST', respectively. The number ' 10 ' was added because we adopted a threshold of $10^{\circ} \mathrm{C}$ for evaluation of trends in spring and autumn temperature. Seip (2015) also used an SST threshold of $10^{\circ} \mathrm{C}$ for defining the growing season in the Gulf of Maine.

\subsection{Definition of seasons}

For some calculations, the seasons are considered separately (Figs. S1-S3 in the Supplement at www. int-res.com/articles/suppl/m622p001_supp.pdf). These are defined by months as in the HELCOM community (e.g. HELCOM 1996) and are mainly based on the occurrence of the spring, summer and autumn blooms. Accordingly, in the Bay of Mecklenburg, spring extends from February to April, summer from May to August and autumn from September to November. As winter extends from December to January we define, for example, 'winter 1989' as the months December 1988 and January 1989. Monthly means were calculated first as the basis for further calculations of seasonal mean values.

\subsection{Statistical analyses}

We applied the non-parametric Mann-Kendall test (Kendall 1975) for monotonic downward or upward trends together with the non-parametric Sen method (Sen 1968) for the slope estimate. This test allows outliers and does not need any particular distribution of the data. It cannot be applied for highly non-linear trends. The calculation spreadsheet and a manual are supplied by Salmi et al. (2002). Since $n>10$, the $Z$ statistic (normal approximation) could be applied. The results are shown in Table 1. The coefficients of determination $\left(\mathrm{r}^{2}\right)$ given in Figs. 3, 4, 7, 8 and S1-S4 were derived from the linear trend lines provided by Excel, and were used to calculate $t$. The correlations shown in Table 2 are significant if $t>\mathrm{p}$ for $\mathrm{p}$-levels 0.05 and 0.01 . The contour graphs in Figs. 9-11 were produced from monthly means of phytoplankton biomass in SigmaPlot10.0 with interpolation of missing data.

\section{RESULTS}

\subsection{Abiotic variables}

The measurement and evaluation of physical and chemical data were not the primary aim of our study, but they were necessary for the interpretation and discussion of the biological results. The local salinity, temperature and nutrient conditions at the time of sampling were highly variable and dependent on the wind-induced mixing, upwelling processes and currents. Seasonal averages, as presented in the Supplement (Figs. S1-S4), smooth these variations. More stable and representative temperature data can be gained from weekly averages derived from daily SST data covering the central Bay of Mecklenburg, which form the basis for the estimates shown in Fig. 3.

As an indicator for warming, the seasonal advancement of DF-SST10 and the delay of DL-SST10 are shown in Fig. 3a. The period between these threshold days (DD-SST10) expanded over the study period

Table 1. Significance of trends for 1989 to $2017-{ }^{\#} p \leq 0.1,{ }^{*} p \leq 0.05,{ }^{* *} p \leq 0.01,{ }^{* * *} p \leq 0.001$. (+) Increase; (-) decrease; Temp.: temperature at sampling station; DL-SST10: end of the annual period with SST $>10^{\circ} \mathrm{C}_{\text {; }}$ empty cells: non-significant. Winter data of the variables shown did not reveal significant trends

\begin{tabular}{|lcccccc|}
\hline Season & Salinity & Temp. & Sunshine duration & Nitrate & Silicate & Phosphate \\
\hline Spring & & & $+^{\#}$ & $-^{* *}$ & & $-^{*}$ \\
Summer & & $+^{\#}$ & $+^{* * *}$ & $-^{* *}$ & $+^{*}$ & $-^{*}$ \\
Autumn & $+^{*}$ & $+^{* *}$ & & & $-^{* *}$ & $+^{* *}$ \\
\hline
\end{tabular}

Table 2. Coefficient of determination $\left(\mathrm{r}^{2}\right)$ for correlations of seasonal means of different variables in spring and autumn, 1989 to 2017 (silicate since autumn 1994), with the duration of the chl a-based growing season (DD-C). ${ }^{*} p \leq 0.05,{ }^{* *} p \leq 0.01$. The number of days with SST $>10^{\circ} \mathrm{C}$ (DD-SST10) covers the entire year (i.e. all seasons). Temp.: temperature at sampling station

\begin{tabular}{|c|c|c|c|c|c|c|c|}
\hline Season & Salinity & Temp. & Sunshine duration & Nitrate & Silicate & Phosphate & DD-SST10 \\
\hline Spring & 0.076 & 0.016 & $0.298^{* *}$ & $0.217^{*}$ & 0.097 & $0.432^{* *}$ & \multirow{2}{*}{$0.268^{* *}$} \\
\hline Autumn & $0.220^{*}$ & $0.349^{* *}$ & 0.002 & $0.160^{*}$ & 0.142 & $0.411^{* *}$ & \\
\hline
\end{tabular}



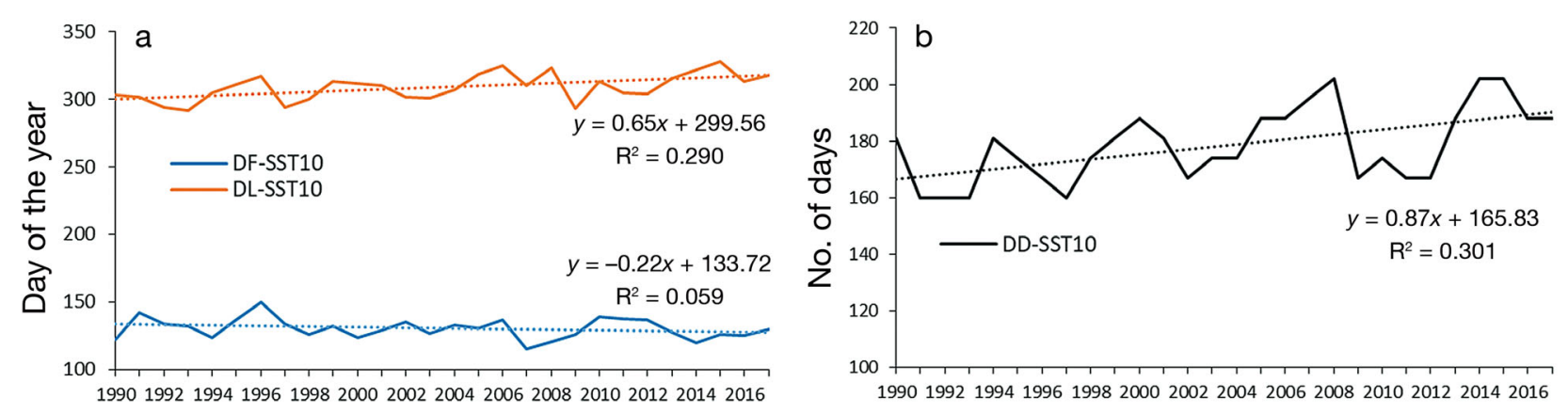

Fig. 3. Trends for 1990 to 2017 of the (a) start (DF-SST10) and end (DL-SST10) and (b) duration of the period (DD-SST10) with $\mathrm{SST}>10^{\circ} \mathrm{C}$ in the Bay of Mecklenburg

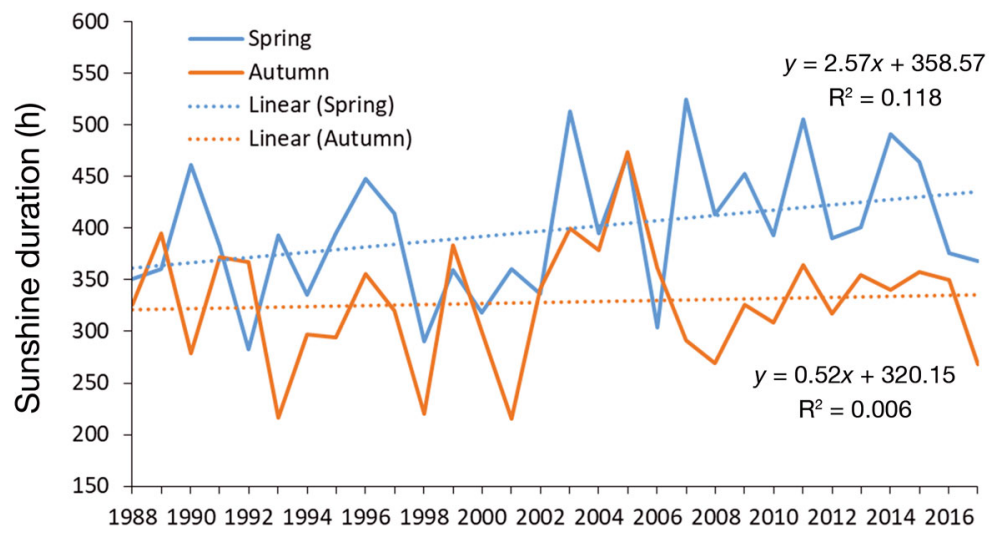

Fig. 4. Trends for 1988 to 2017 in the cumulative sum of sunshine duration in spring and autumn in the Bay of Mecklenburg

(Fig. 3b). The significance of trends is shown in Table 1. Increasing or decreasing trends are marked with ' + ' and ' - ', respectively, and can also be seen from the regression lines in the corresponding figures (Figs. 3, 4, S1 \& S2). The increase in DL-SST10 is significant (Table 1), but the decrease in DF-SST10 is not.

The cumulative sum of sunshine duration increased in the spring data from 1988 to 2017 (Fig. 4). This trend is only weakly significant due to strong fluctuations (Table 1). The autumn data for sunshine duration show no trend at all. Significant trends in local temperature and salinity data occurred in autumn but not in spring (Fig. S1). Nitrate and phosphate showed decreasing trends both in spring and autumn, whereas silicate concentrations increased in summer (Fig. S2, Table 1).

\subsection{Biotic variables}

The complete time-series of phytoplankton biomass and chl a data taken from June 1988 to Decem- ber 2017 are shown in Figs. 5 \& 6, respectively. For further calculations (see Figs. $7 \&$ 8), we considered only the full years, starting with 1989 .

The growing season extended from about Day 100 to 250 in the first years until 1992, except the early spring bloom in 1991 (Figs. 5a \& 6a). In the years from 1993 to 1998, some spring blooms already started on Day 65 and the autumn blooms ended on Day 270 to 310 (Figs. 5b \& 6b). It has to be mentioned that phytoplankton data from September to December 1994 and from the whole of 1997 are lacking, but chl a data are available. In the period from 1999 to 2003, spring blooms occurred already between Days 50 and 100 and autumn blooms could extend to Day 336 (Figs. 5c \& 6c). The last biomass value available for 2003 was from 2 December (Day 336; $756 \mathrm{mg} \mathrm{m}^{-3}$ ) and was accepted as DL because chl a data from the following sampling days showed a strong decrease. The same strategy was applied in 2008 when the last biomass value of that year (on 16 December, Day 351) was still high but was assumed as the biomass DL because chl a was already decreasing below the threshold. Neither biomass nor chlorophyll samples were taken in 2006 after 23 October. Therefore, the end of the growing season could not be reliably identified in 2006. Many phytoplankton samples from spring 2013 could not be analysed because of a high proportion of sediment particles. There was not enough biomass data from this year for a realistic representation of the spring situation, and a calculation was not possible for that season. However, chl a data were present.

In general, earlier spring blooms and later autumn blooms (Fig. 7) led to an expansion of the growing season (Fig. 8). All linear trends shown in Figs. 7 \& 8 

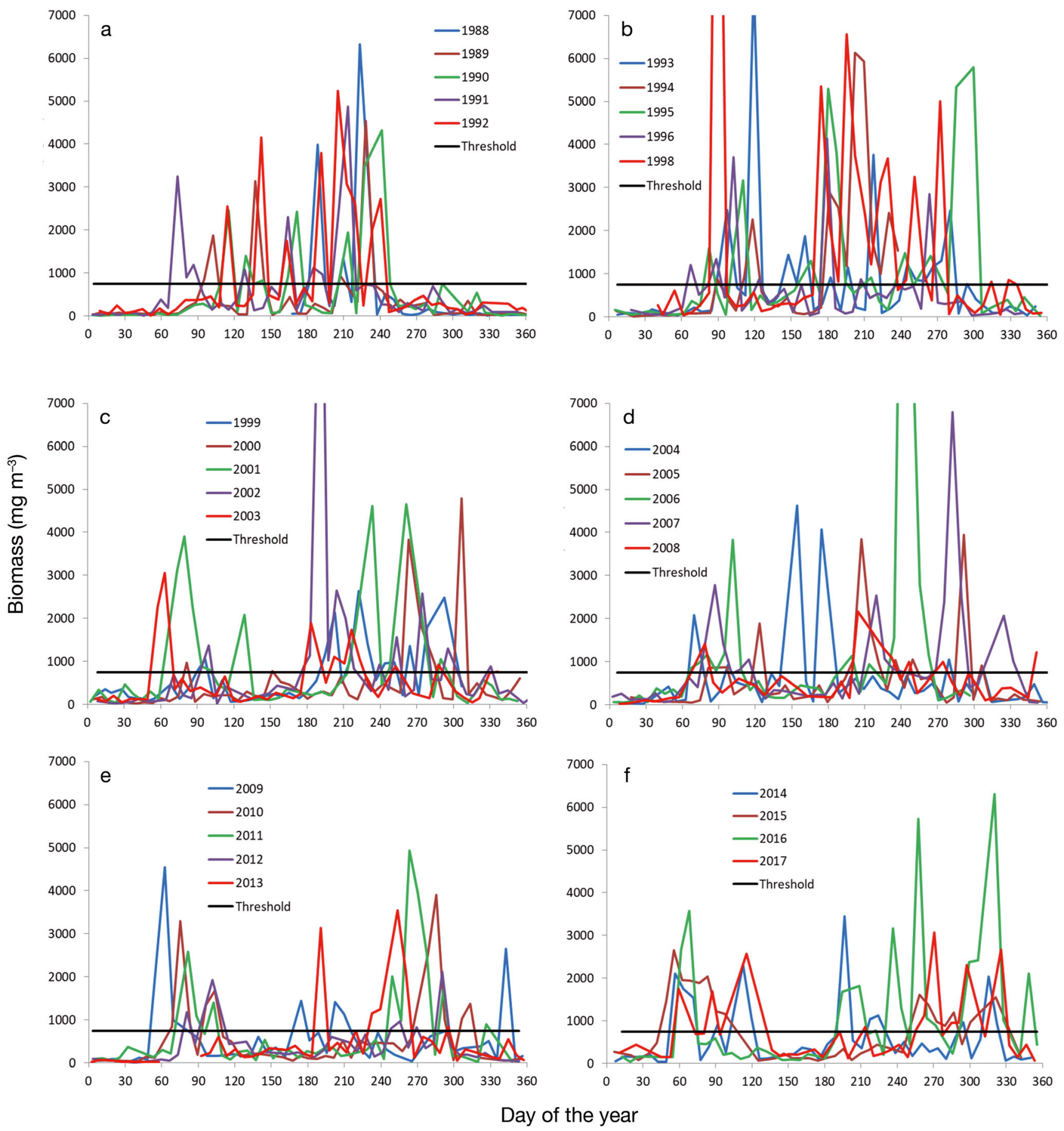

Fig. 5. Phytoplankton biomass (wet weight) data from the coastal station for every investigation year. (a) 1988-1992, (b) 1993-1998, (c) 1999-2003, (d) 2004-2008, (e) 2009-2013, (f) 2014-2017

by dashed lines are highly significant. The increase in the duration of the growing season, expressed in number of days, is of special interest. We prefer using regression line estimates of the trends instead of the discrete values measured at the beginning and the end of the data series, because they are more repre- sentative than single measuring points. The estimate based on the regression lines suggests an increase in DD from 159 d in 1989 to 284 d in 2017 for the biomass data, and from 163 d in 1989 to 292 d in 2017 for the chl a data. Thus, the duration of the growing season increased by 125 or 129 d based on biomass or 

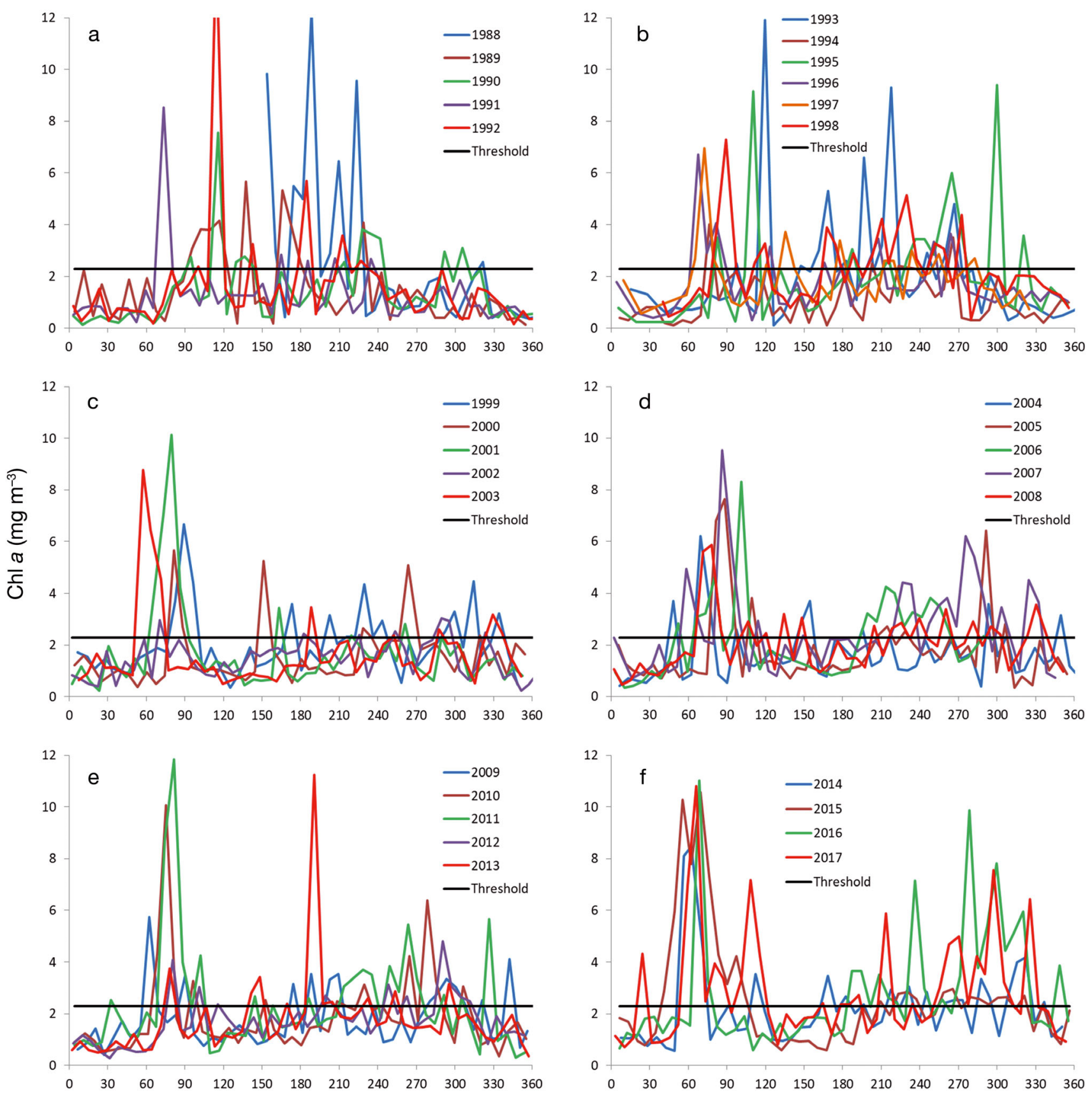

Day of the year

Fig. 6. Chl a data from the coastal station for every investigation year. (a) 1988-1992, (b) 1993-1998, (c) 1999-2003, (d) 20042008, (e) 2009-2013, (f) 2014-2017

chl a data, respectively. The $29 \mathrm{yr}$ period relates to 28 inter-annual time-steps. Division of the total number of days by 28 results in a rate of $1.4 \mathrm{~d} \mathrm{yr}^{-1}$ for the earlier spring bloom and $3.1 \mathrm{~d} \mathrm{yr}^{-1}$ for the delay to the end of the autumn bloom. The growing season thus extended by $4.5 \mathrm{~d} \mathrm{yr}^{-1}$ in the period from 1989 to 2017.
The extension of the growing season did not necessarily lead to higher annual phytoplankton production or biomass, because the spring and autumn blooms did not increase in length but tended to shift from summer to spring and autumn. Therefore, the biomass trends in the fixed spring and autumn periods did increase, whereas the summer biomass data 

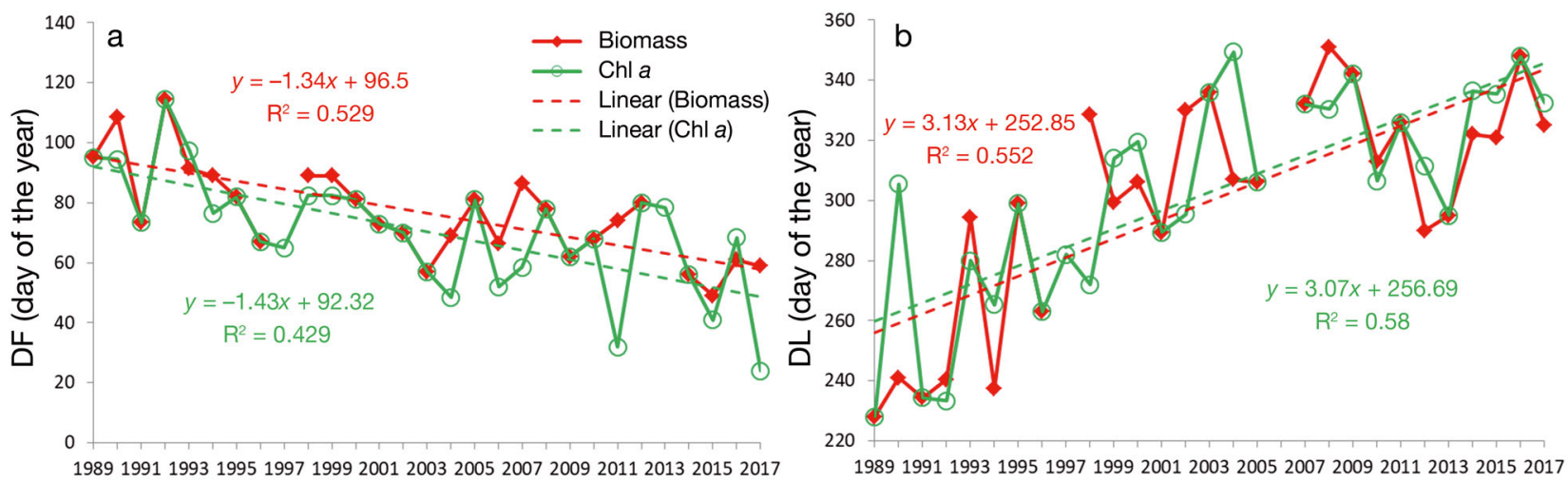

Fig. 7. Trends in the (a) start of the spring bloom (DF) and (b) end of the autumn bloom (DL) with regression lines and corresponding formulas

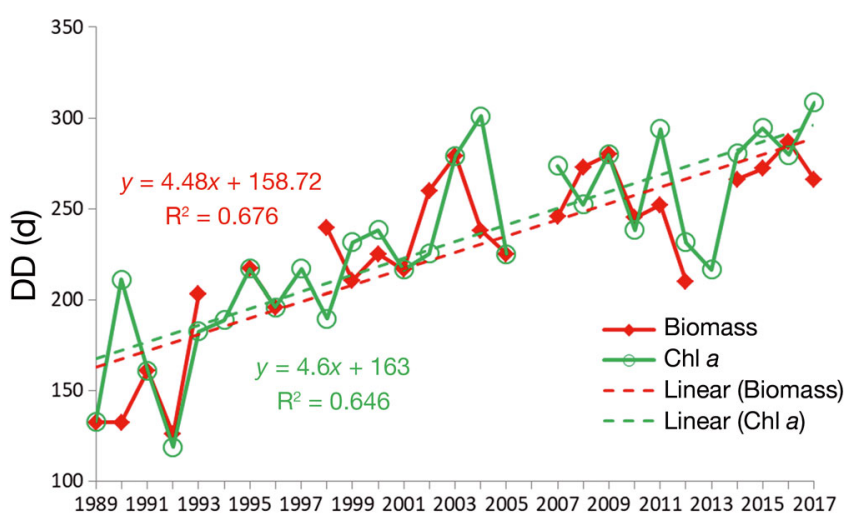

Fig. 8. Trends in the duration of the growing season (DD) with regression lines and corresponding formulas

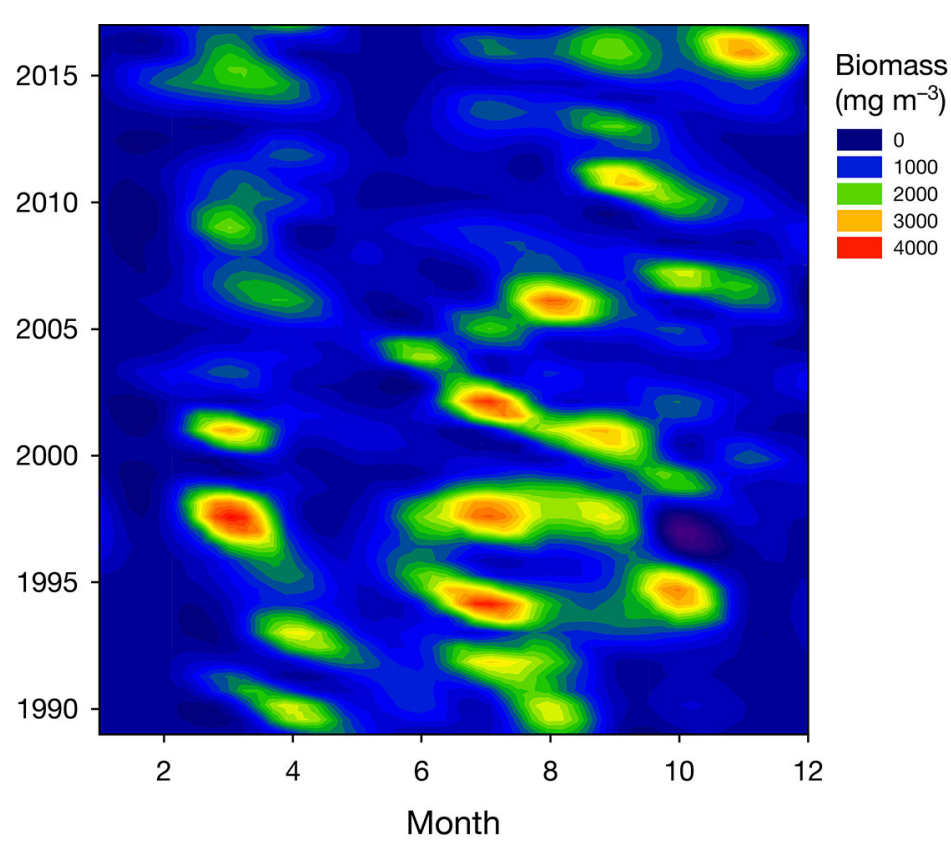

Fig. 9. Seasonal and long-term development of total phytoplankton biomass showed a decreasing trend (Fig. S3). A prolongation of the summer minimum period becomes obvious from the successive graphs presented in Figs. $5 \& 6$ and from Fig. 9. This primarily shows a shift in the autumn bloom.

The question is whether the change in timing is related to shifts in species composition. The most important classes are the Bacillariophyceae and Dinophyceae, contributing $68 \%$ to total phytoplankton biomass if all data are considered. Bacillariophyceae and Dinophyceae contributed 40 and $24 \%$, respectively, to total phytoplankton biomass during the spring months and 54 and $31 \%$ during the autumn months. They were the only classes that showed a clear shift in their distribution (Fig. 10), whereas the remaining classes showed scattered patterns.

The dominating spring species was Skeletonema marinoi, with $15 \%$ of the total phytoplankton biomass. This was the only abundant spring species that showed a clear tendency towards earlier blooms, shifting from May to February/March (Fig. 11a). Other species appeared sporadically in high biomass, as for example an unidentified small Chaetoceros species on 30 March 1998 (not shown). A diatom that formed summer blooms up until 2005, Dactyliosolen fragilissimus, tended to occur in autumn after 2005 (Fig. 11b). Some diatoms (Cerataulina pelagica, Pseudosolenia calcar-avis) appeared as new bloom-forming species in autumn (Fig. 11c,d). Other taxa, such as Rhizosolenia setigera and Actinocyclus spp., could occur both in spring and in autumn (Fig. 11e,f). The autumn diatom species mentioned, except Actinocyclus spp., are marine species that 

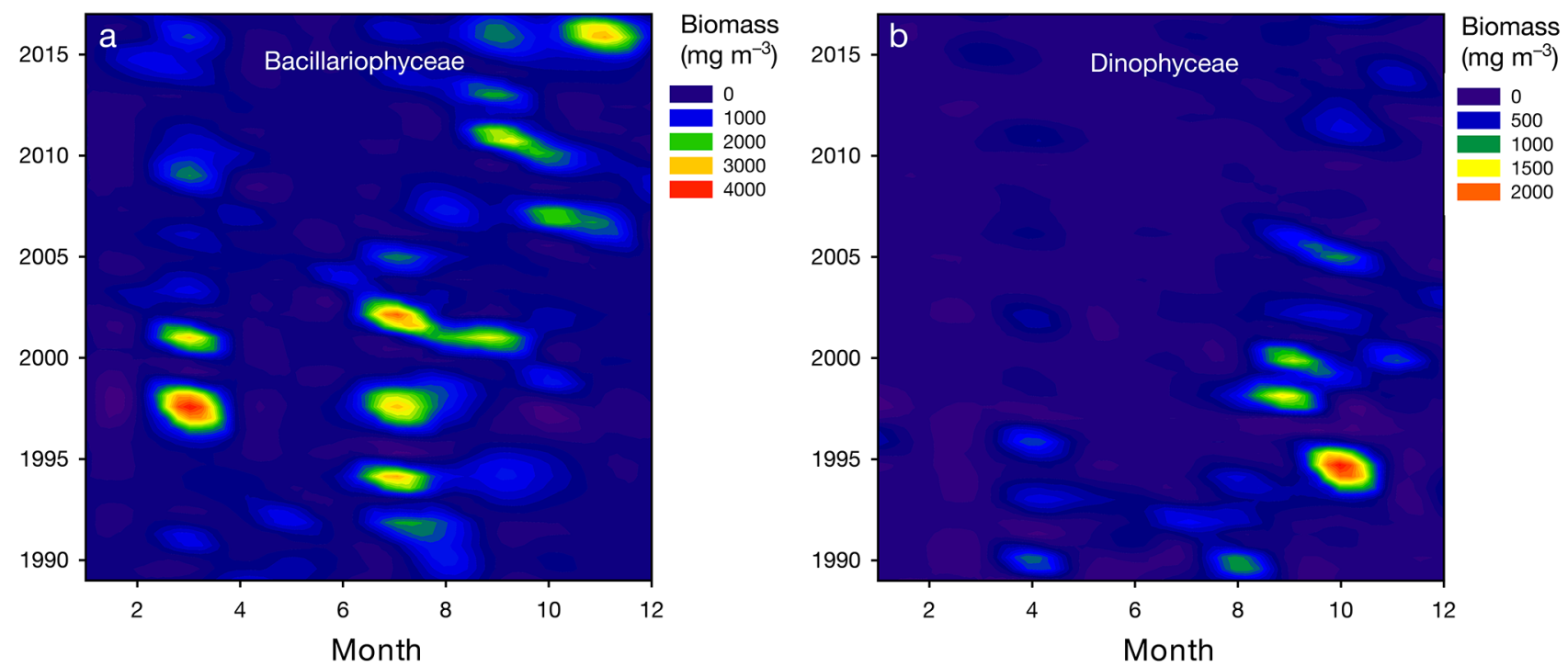

Fig. 10. Seasonal und long-term development of biomass of (a) Bacillariophyceae and (b) Dinophyceae. Note the different colour scales

may become progressively established in the Bay of Mecklenburg with a corresponding increase in salinity (Table 1).

The Dinophyceae were predominantly represented by Ceratium spp., with a maximum in October 1998. The distribution pattern of this genus was almost identical to that shown in Fig. 10b.

\section{DISCUSSION}

The relationship between phytoplankton biomass and chl a concentration is variable. Therefore, independent calculations based on these 2 parameters may not always agree. For example, no autumn bloom was identified in the biomass data in 1990, whereas the chl a data suggest a small autumn bloom (Days 291 to 305; Figs. 5a \& 6a). Raising the chl a threshold would bring the biomass and chl a calculations for 1990 into agreement. On the other hand, if we reduced the chl a threshold to $2.0 \mathrm{mg} \mathrm{m}^{-3}$, we could harmonize the deviating DL-B with DL-C and DD-B with DD-C for 1998 (Figs. 7b \& 8). The chl a maximum of the spring bloom in 2002 (2.95 $\mathrm{mg} \mathrm{m}^{-3}$ on Day 70 ) corresponded to a phytoplankton biomass of only $695 \mathrm{mg}$ $\mathrm{m}^{-3}$, which was slightly below the threshold, but was accepted as the first high biomass value (DF-B) of the season as this agreed with DF-C. Adopting different thresholds for different years depending on the magnitude of the annual chl a data would be a theoretical solution, but appears rather subjective and was not applied. Instead, we preferred to use a constant threshold, as was applied by Kahru et al. (2016). Consequently, we kept the discrepancies shown in Figs. 7 $\& 8$ in order to indicate the spread of our estimates.

The threshold level should exclude small prebloom and post-bloom biomass peaks that could be caused by sediment resuspension after storm events. This was not always realized. For example, chl a peaks occurred on 1 February 2011 and 24 January 2017 without corresponding biomass peaks, and may be considered as outliers. In order to exclude subjective decisions on outliers, we generally kept all data including these 'outliers', even if they disturbed the smooth outlook of the data series. They indicate some degree of uncertainty in the results.

Using diverse data of terrestrial organisms (herbs, shrubs, trees, birds, butterflies, amphibians), Parmesan \& Yohe (2003) estimated a mean shift towards an earlier occurrence of spring events of $2.3 \mathrm{~d}$ per decade. This is very little in comparison to reports concerning aquatic systems (e.g. Edwards \& Richardson 2004). For phytoplankton, we found a much higher trend for earlier spring blooms of approximately $14 \mathrm{~d}$ per decade and a delay to the end of the autumn blooms of $31 \mathrm{~d}$ per decade in the period from 1989 to 2017. Obviously, the extension of the growing season is due much more to the longer autumn blooms than the earlier spring blooms. Kahru et al. (2016) found a similar phenomenon: trends towards an earlier start and later end of the growth season. Their data revealed an advance of $16 \mathrm{~d}$ per decade in the spring bloom and a delay to the end of the high chl a period at a mean rate of $19 \mathrm{~d}$ per decade. 

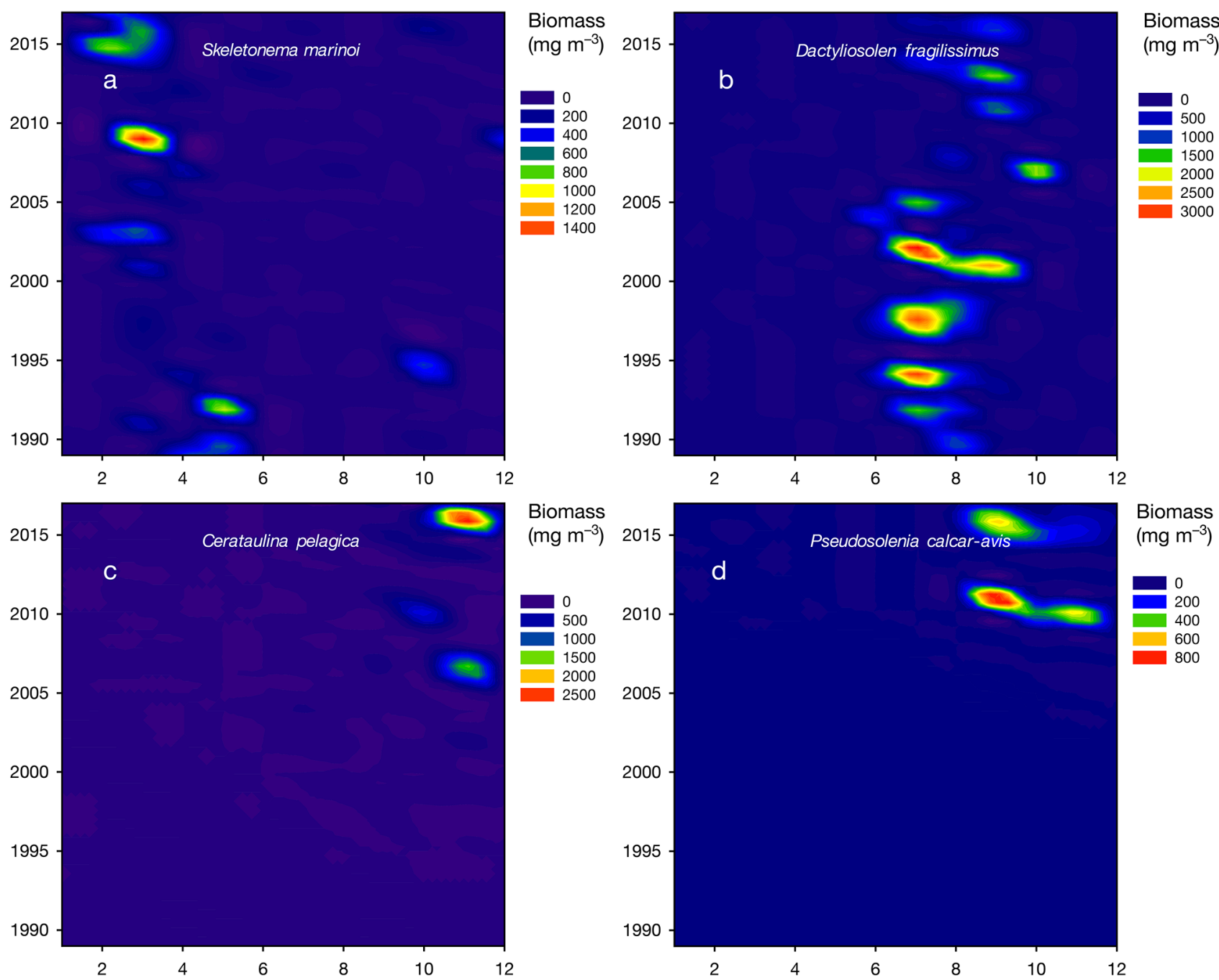

Biomass $\left(\mathrm{mg} \mathrm{m}^{-3}\right)$
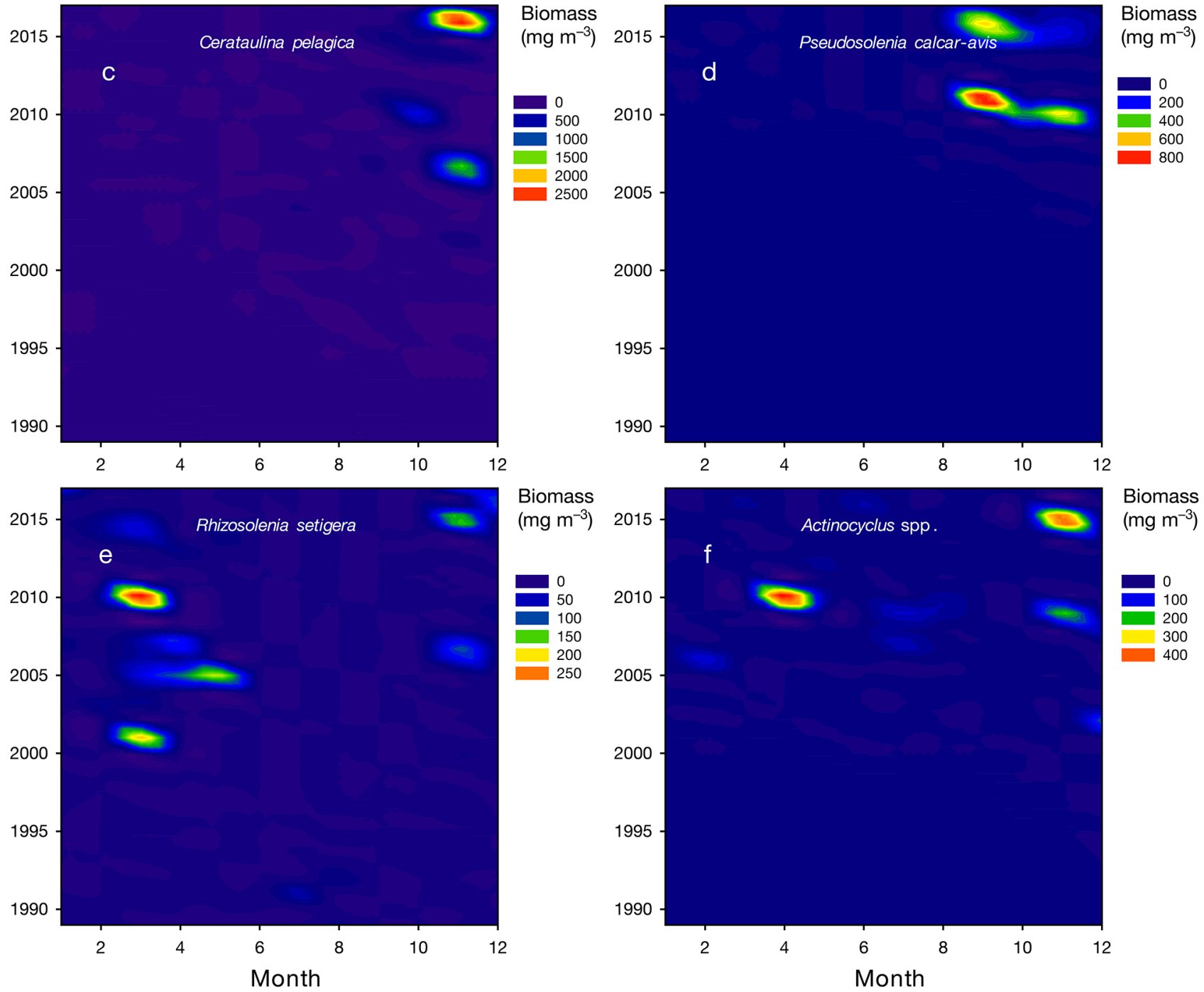

Fig. 11. Seasonal und long-term development of biomass of important diatom taxa. (a) Skeletonema marinoi, (b) Dactyliosolen fragilissimus, (c) Cerataulina pelagica, (d) Pseudosolenia calcar-avis, (e) Rhizosolenia setigera, (f) Actinocyclus spp. Note the different colour scales 
Our study ascertained a clear extension of the phytoplankton growing season by $127 \mathrm{~d}$ (mean of biomass- and chl a-based data) within $28 \mathrm{yr}$, which corresponds to $4.5 \mathrm{~d} \mathrm{yr}^{-1}$. Kahru et al. (2016) detected a 110 d prolongation from 1998 to 2013 in the open Baltic Sea, which is equivalent to $7.3 \mathrm{~d} \mathrm{yr}^{-1}$. The data presented by Kahru et al. (2016) and our conservative estimate represent a range of past developments. It is, however, important to note that these linear trends cannot be projected into the future.

The extension of the growing season is more or less correlated with the variables tested (salinity, temperature, sunshine duration, nutrient concentrations; Table 2). Variables with increasing trends correlated with the extension of the growing season. Salinity showed a significant increase only in the autumn data (Fig. S1d, Table 1). Increasing salinity indicates inflow of water from the Kattegat, and probably a long-term increase in autumn storms. The inflowing water contains species of marine origin, whose additional biomass may prolong the growing season. Generally, we consider salinity to be less important for the phenological changes

The winter season is preferred for long-term analyses of nutrient concentrations, as this represents the most stable situation with highest concentrations and minimum biological activity (Nausch et al. 2008). However, no significant trends in winter nutrient concentrations were found, i.e. the 'winter' row would be empty in Table 1. In the phytoplankton growth phase, dissolved inorganic nutrients are consumed, leading to rapid changes. The high pre-bloom and the low postbloom nutrient concentrations should be separated within a season. However, even our weekly data are too approximate for detailed analyses of the nutrient-phytoplankton relationship and kinetics during the bloom development, particularly as short-term resuspension and advection processes cause high variability. Therefore, we simply present the seasonal means of nutrients which include the wide range from pre-bloom and post-bloom situations (Fig. S2). Nevertheless, some correlations between nitrate and phosphate concentrations and duration of the growing season could be detected (Table 2, Fig. S4d). The consumption of dissolved inorganic nutrients during phytoplankton growth generally leads to a negative correlation between nutrient concentrations and phytoplankton biomass on a short-term scale. We believe that the statistical correlations between nutrient concentrations and the duration of the growing season do not indicate decisive causal relationships.

Usually, light and temperature are considered to be stimulants of phytoplankton growth as long as nutri- ents are available, which is the case in early spring (Sommer et al. 2012a, Edwards et al. 2016). Light is a basal resource for phytoplankton, whereas lightsaturated growth rates depend largely on temperature. Temperature also influences growth indirectly, e.g. via stratification, which increases the mean light exposure of phytoplankton cells in the mixed surface layer. Several field data suggest that the onset of the spring bloom in shallow water bodies, in contrast to stratified deeper waters, is independent of the onset of thermal stratification (Sommer \& Lengfellner 2008). In mesocosm experiments simulating shallow, wellmixed systems, the timing of the spring bloom was found to be strongly coupled to the external light regime, with an almost 1.5 mo earlier spring peak at high light in comparison with the low-light treatment, whereas higher temperature accelerated the spring peak by only 1 to $1.4 \mathrm{~d}^{\circ} \mathrm{C}^{-1}$ (Sommer \& Lengfellner 2008). Another mesocosm experiment conducted in the same area (Kiel Fjord) confirmed the importance of light: high-light treatment shifted the spring bloom to the end of January, whereas it usually occurs in February (Sommer et al. 2012b). The evaluation of an extended set of mesocosm experiments with water from Kiel Fjord showed lower and less consistent effects of light on spring-bloom timing (Winder et al. 2012).

We have no data for irradiance and turbidity from our sampling station. As a proxy for irradiance, we used sunshine duration, which showed an increase in spring data (Fig. S4c), probably because of reduced cloudiness, although according to Kahru et al. (2016), cloudiness has increased in a long-term comparison of winter data. The incoming shortwave irradiation showed typical annual cycles without any trend, but its cumulative daily sum was reached earlier in spring and summer over the whole investigation period, indicating slightly higher irradiation after mid March over the Baltic Sea (Kahru et al. 2016). In addition, underwater light intensity may have increased because of increased water transparency, as reported, for example, by Fleming-Lehtinen \& Laamanen (2012) for the southern Baltic Sea. Usually, light limitation of growth is assumed in early spring and late autumn (Hegseth \& Sakshaug 1983). Therefore, the large extension of the autumn bloom is surprising. Mixotrophic species, such as Ceratium spp., are however largely independent of light (Tunin-Ley et al. 2009). They may become more dominant with climate change (Flynn et al. 2013). If they are not grazed and do not sink out, they may stay in the water column with low metabolic activity and only appear to be undergoing a longer growth phase in autumn. 
A longer warming period in summer leads to a longer warm phase in autumn. Therefore, the temperature increase in autumn, in contrast to that in spring, was strongly significant (Fig. S1, Table 1), and the end of the annual period with $\mathrm{SST}>10^{\circ} \mathrm{C}$ (DL-SST10) shifted significantly towards the end of November (Fig. 3, Table 1). A later autumn bloom and a shorter resting period in winter may allow survival of a higher phytoplankton biomass as an early starting population for the following spring (Thackeray et al. 2008, Schlüter et al. 2012).

A temperature effect on the phenology of the spring bloom has been described in the literature, but could not be confirmed with our data. In mesocosms filled with water from Kiel Fjord, Sommer \& Lewandowska (2011) found that the spring phytoplankton peak occurred $1 \mathrm{~d}$ earlier per $1^{\circ} \mathrm{C}$ warming. The mesocosm experiments of Feuchtmayr et al. (2010) showed an advance of the chl a peak by 15 to $19 \mathrm{~d}$ with a $4^{\circ} \mathrm{C}$ temperature increase. Seip (2015) ascertained that an increase of $1^{\circ} \mathrm{C}$ starts the 'growing season' $8 \mathrm{~d}$ earlier and lengthens the season by $13 \mathrm{~d}$ (for $\mathrm{SST}>10^{\circ} \mathrm{C}$ ) in the Gulf of Maine. The reasons for this temperature effect are hard to explain, because phytoplankton growth is primarily dependent on light and nutrients, and much less affected by temperature than zooplankton.

Higher temperature stimulates zooplankton more than phytoplankton because of their higher metabolic response to temperature (O'Connor et al. 2009, Winder et al. 2012). Zooplankton cannot grow before its food source has developed (Thackeray 2012). As temperature increase stimulates zooplankton activity more strongly than phytoplankton activity, the time lag between the phytoplankton peak and microzooplankton biomass is reduced (Aberle et al. 2012). This indicates that the mismatch hypothesis should be rejected (Atkinson et al. 2015). Grazing might be an important factor in the termination of the bloom, but not in preventing its initiation if light and nutrients are adequate (Nixon et al. 2009). We may assume that the phenological shift in spring phytoplankton is rather independent of zooplankton (cf. Sommer \& Lewandowska 2011). Englund et al. (2011) showed a clear increase in zooplankton attack rate on phytoplankton and maximum ingestion rate with temperature increase within the natural temperature range. Correspondingly, raised temperature may lead to a decrease in phytoplankton biomass (Sommer \& Lewandowska 2011, Paul et al. 2015, 2016).

Phenological changes may depend on the appearance of species which may react in different manners (Thackeray et al. 2008). Warm-stenothermic species may invade warmer waters, whereas cold-stenothermic species may escape to colder areas, greater depths or colder seasons. Shifts in seasonal occurrence can be identified clearly by comparison with historical data sources. The dinoflagellates, primarily represented by Ceratium spp. such as C. tripos (= Tripos muelleri), C. fusus, C. lineatum and C. furca, had maximum biomass in Kiel Bay in August 1905 and 1906 (Lohmann 1908), in August to October 1949 (Gillbricht 1951) and in September to November 2001 to 2003 (Wasmund et al. 2008). A shift from summer to late autumn occurred within a century. Historical literature for Ceratium spp. has also been used for long-term studies in the northwestern Mediterranean Sea by Tunin-Ley et al. (2009). The averaged annual cycles of SST in that study again showed a longer warm season at present in comparison to those in the past. C. tripos, C. fusus and C. furca were more or less perennial, but they had a minimum in the warm season in the Monaco vertical sampling data (Tunin-Ley et al. 2009).

Skeletonema marinoi, previously named $S$. costatum, is currently the most abundant diatom in the Bay of Mecklenburg and in the Arkona Basin. It can form spring blooms even in the Gulf of Finland, but with great year-to-year fluctuations which cannot be directly connected with changes in environmental conditions (Kononen \& Niemi 1984). In Kiel Bay, its biomass was highest within the period from May to October in 1905 and 1906 (Lohmann 1908), shifted to March in 1950 (Gillbricht 1951) and even to February in 2003 (Wasmund et al. 2008). This shift from a summer/autumn species to an early spring species is remarkable. However, Borkman \& Smayda (2009) and Nixon et al. (2009) found the opposite trend in Narragansett Bay from 1959 to 1997 or 2006: a longterm decline in the winter/spring populations and an increase in summer/autumn populations of $S$. costatum, related to trends from cold winters to warmer winters. This discrepancy with our findings may be explained by a recent reassessment of the species after the taxonomic revision by Sarno et al. (2005). This revealed that the winter species in Narragansett Bay is $S$. japonicum and the summer species is S. grethae (Nixon et al. 2009). Perhaps the Skeletonema species of historic summer/autumn blooms in Kiel Bay was also different from the recent spring species $S$. marinoi.

Concerning historical data of diatoms that are currently important in Kiel Bay, Dactyliosolen fragilissimus (=Rhizosolenia fragilissima) and $R$. setigera had their relatively low biomass peaks in July to September, whereas Cerataulina pelagica (C. bergonii) 
was unimportant and Pseudosolenia calcar-avis (R. calcar-avis) and Actinocyclus spp. were not mentioned at all in 1905 and 1906 (Lohmann 1908). From these 5 taxa, Gillbricht (1951) mentioned only $D$. fragilissimus and $C$. pelagica, mainly from June to August and from October 1949, respectively. In 2002 and 2003, R. setigera became a spring species but $C$. pelagica an autumn species, whereas $D$. fragilissimus stayed a summer species in Kiel Bight (Wasmund et al. 2008). In our recent data from the Bay of Mecklenburg, $D$. fragilissimus shifted its blooms from summer to autumn after 2005. According to Ignatiades \& Smayda (1970), D. fragilissimus does not grow below $9^{\circ} \mathrm{C}$, which explains why it was originally a summer species and may shift to autumn with increasing temperature. While $D$. fragilissimus occurs primarily in summer in Narragansett Bay, $R$. setigera is a species of winter/spring (Karentz \& Smayda 1984). The latter finding is supported by our data, and it may also apply to Actinocyclus spp., which are primarily represented by $A$. octonarius.

P. calcar-avis has formed strong autumn blooms in some recent years (cf. Kaiser et al. 2016). Historical data from the North Sea show that P. calcar-avis used to occur mainly in autumn and winter, but it prefers warmer regions, e.g. the Adriatic and the Gulf of Mexico (Kraberg et al. 2015). This species seems to be now extinct in the North Sea as Kraberg et al. (2015) could not find any recent records after those from 1906 to 1908. Therefore, its recent entry from the North Sea is unlikely. However, this species has been found to be present in sediments of the Baltic Sea (Tuovinen et al. 2008). This sudden appearance in the Baltic Sea was surprising because no simultaneous environmental changes occurred. It shows that trends on the species level cannot be well explained on the basis of the limited set of environmental data available.

In general, we found a shift of some abundant taxa from summer to spring (Skeletonema sp.) or autumn (Ceratium spp., D. fragilissimus, C. pelagica) or even to both spring and late autumn ( $R$. setigera). New species may further enhance the biomass in autumn (P. calcar-avis). The appearance of some bloomforming species is scattered and remains difficult to predict because it may also depend on biotic interactions, including conditions for encystment/excystment. Unravelling the complicated patterns on the species level would need additional extensive research.

We conclude that phytoplankton has extended its growing season to February-December in coastal waters of the western Baltic Sea. It is much more subject to phenological changes than terrestrial plants.
A problem in comparison with rooted terrestrial plants is the high variability in data due to the motility of the water bodies containing phytoplankton. Biomass changes may misleadingly be interpreted as real growth or loss processes if different water bodies are drifting past a fixed station, which is a general problem in dynamic systems (Atkinson et al. 2015).

Light is a primary resource, whereas temperature is of secondary importance for primary production. The increased sunshine duration during spring may have caused an earlier spring bloom. The corresponding earlier nutrient exhaustion, probably together with higher grazing activity due to increased summer temperature, caused a longer summer gap for phytoplankton biomass. The higher temperatures in autumn enabled longer autumn blooms, probably induced by changes in species composition, altered grazing activity, a prolonged remineralization phase and/or reduced settling rates. A larger overwintering population may give rise to earlier development in the spring.

Acknowledgements. We thank our colleagues Jenny Jeschek and Lars Kreuzer for their support in the sampling activities. The data were processed and uploaded into the data base of the Leibniz Institute for Baltic Sea Research Warnemünde (IOW) by Dr. Steffen Bock, Dr. Susanne Feistel and Solvey Hölzel. They are available from the IOW data host and are licensed under Creative Commons 4.0 (CC BY 4.0). The sea surface temperature data were provided by the Bundesamt für Seeschifffahrt und Hydrographie. We thank Ms. Tschersich for cooperation.

\section{LITERATURE CITED}

Aberle N, Bauer B, Lewandowska A, Gaedke U, Sommer U (2012) Warming induces shifts in microzooplankton phenology and reduces time-lags between phytoplankton and protozoan production. Mar Biol 159:2441-2453

Atkinson A, Harmer RA, Widdicombe CE, McEvoy AJ and others (2015) Questioning the role of phenology shifts and trophic mismatching in a planktonic food web. Prog Oceanogr 137:498-512

* Borkman DG, Smayda T (2009) Multidecadal (1959-1997) changes in Skeletonema abundance and seasonal bloom patterns in Narragansett Bay, Rhode Island, USA. J Sea Res 61:84-94

Cleland EE, Allen JM, Crimmins TM, Dunne JA and others (2012) Phenological tracking enables positive species responses to climate change. Ecology 93:1765-1771

Cloern JE, Abreu PC, Carstensen J, Chauvaud L and others (2016) Human activities and climate variability drive fast-paced change across the world's estuarine-coastal ecosystems. Glob Chang Biol 22:513-529

Edwards M, Richardson AJ (2004) Impact of climate change on marine pelagic phenology and trophic mismatch. Nature 430:881-884

Edwards KF, Thomas MK, Klausmeier CA, Litchman E (2016) Phytoplankton growth and the interaction of light 
and temperature: a synthesis at the species and community level. Limnol Oceanogr 61:1232-1244

Englund G, Ohlund G, Hein CL, Diehl S (2011) Temperature dependence of the functional response. Ecol Lett 14: 914-921

Feuchtmayr H, Moss B, Harvey I, Moran R, Hatton K, Connor L, Atkinson D (2010) Differential effects of warming and nutrient loading on the timing and size of the spring zooplankton peak: an experimental approach with hypertrophic freshwater mesocosms. J Plankton Res 32: 1715-1725

Fleming-Lehtinen V, Laamanen M (2012) Long-term changes in Secchi depth and the role of phytoplankton in explaining light attenuation in the Baltic Sea. Estuar Coast Shelf Sci 102-103:1-10

Flynn KJ, Stoecker DK, Mitra A, Raven JA and others (2013) Misuse of the phytoplankton-zooplankton dichotomy: The need to assign organisms as mixotrophs within plankton functional types. J Plankton Res 35:3-11

Gillbricht M (1951) Produktionsbiologische Untersuchungen in der Kieler Bucht. PhD dissertation, Kiel University

Grasshoff K, Ehrhardt M, Kremling K (1983) Methods of seawater analysis, 2nd edn. Verlag Chemie, Weinheim

*Hallegraeff GM (2010) Ocean climate change, phytoplankton responses, and harmful algal blooms: a formidable predictive challenge. J Phycol 46:220-235

*Hegseth EN, Sakshaug E (1983) Seasonal variation in lightand temperature-dependent growth of marine planktonic diatoms in in situ dialysis cultures in the Trondheimsfjord, Norway $\left(63^{\circ} \mathrm{N}\right)$. J Exp Mar Biol Ecol 67: 199-220

HELCOM (Baltic Marine Environment Protection Commission-Helsinki Commission) (1988) Guidelines for the Baltic Monitoring Programme for the third stage. Part D. Biological determinands. Balt Sea Environ Proc No. 27 D, p 1-161

HELCOM (1996) Third periodic assessment of the state of the marine environment of the Baltic Sea, 1989-1993; background document. Balt Sea Environ Proc No. 64 B p 1-252

HELCOM (2017) Guidelines for monitoring of chlorophyll a. www.helcom.fi/Documents/Action \% 20areas/Monitoring $\% 20$ and \%20assessment/Manuals \%20and\%20Guidelines/ Guidelines\%20for\%20measuring\%20chlorophyll\%20a.pdf

‘ Ibáñez I, Primack RB, Miller-Rushing AJ, Ellwood E and others (2010) Forecasting phenology under global warming. Philos Trans R Soc B 365:3247-3260

Ignatiades L, Smayda TJ (1970) Autecological studies on the marine diatom Rhizosolenia fragilissima Bergon. I. The influence of light, temperature, and salinity. J Phycol 6: 332-339

IPCC (2014) Climate change 2014: synthesis report. Core Writing Team, Pachauri RK, Meyer LA (eds) Contribution of Working Groups I, II and III to the Fifth Assessment Report of the Intergovernmental Panel on Climate Change. IPCC, Geneva

Kahru M, Elmgren R, Savchuk OP (2016) Changing seasonality of the Baltic Sea. Biogeosciences 13:1009-1018

Kaiser J, Belt ST, Tomczak M, Brown TA, Wasmund N, Arz HW (2016) $C_{25}$ highly branched isoprenoid alkenes in the Baltic Sea produced by the marine planktonic diatom Pseudosolenia calcar-avis. Org Geochem 93: 51-58

Karentz D, Smayda TJ (1984) Temperature and seasonal occurrence patterns of 30 dominant phytoplankton spe- cies in Narragansett Bay over a 22-year period (19591980). Mar Ecol Prog Ser 18:277-293

Kendall MG (1975) Rank correlation methods. Charles Griffin, London

Kononen K, Niemi $\AA$ (1984) Long-term variation of the phytoplankton composition at the entrance to the Gulf of Finland. Ophelia Suppl 3:101-110

Kraberg A, Rodriguez N, Salewski CR (2015) Historical phytoplankton data from Helgoland Roads: Can they be linked to modern time series data? J Sea Res 101:51-58

Lohmann H (1908) Untersuchungen zur Feststellung des vollständigen Gehaltes des Meeres an Plankton. Wiss Meeresunters Kiel NF 10:130-370

K Lorenzen CJ (1967) Determination of chlorophyll and pheopigments: spectrophotometric equations. Limnol Oceanogr 12:343-346

Nausch G, Nehring D, Nagel K (2008) Nutrient concentrations, trends and their relation to eutrophication. In: Feistel R, Nausch G, Wasmund N (eds) State and evolution of the Baltic Sea, 1952-2005. John Wiley, Hoboken, NJ, p 337-366

Nehring S (1998) Establishment of thermophilic phytoplankton species in the North Sea: biological indicators of climatic changes? ICES J Mar Sci 55:818-823

Nixon SW, Fulweiler RW, Buckley BA, Granger SL, Nowicki BL, Henry KM (2009) The impact of changing climate on phenology, productivity, and benthic-pelagic coupling in Narragansett Bay. Estuar Coast Shelf Sci 82:1-18

$\mathrm{O}^{\prime}$ Connor MI, Piehler MF, Leech DM, Anton A, Bruno JF (2009) Warming and resource availability shift food web structure and metabolism. PLOS Biol 7:e1000178

Olenina I, Hajdu S, Andersson A, Edler L and others (2006) Biovolumes and size-classes of phytoplankton in the Baltic Sea. Balt Sea Environ Proc No. 106, p 1-144

* Parmesan C, Yohe G (2003) A globally coherent fingerprint of climate change impacts across natural systems. Nature 421:37-42

*Paul C, Matthiessen B, Sommer U (2015) Warming, but not enhanced $\mathrm{CO}_{2}$ concentration, quantitatively and qualitatively affects phytoplankton biomass. Mar Ecol Prog Ser 528:39-51

Paul C, Sommer U, Garzke J, Moustaka-Gouni M, Paul A, Matthiessen B (2016) Effects of increased $\mathrm{CO}_{2}$ concentration on nutrient limited coastal summer plankton depend on temperature. Limnol Oceanogr 61:853-868

* Reusch TBH, Dierking J, Andersson HC, Bonsdorff E and others (2018) The Baltic Sea as a time machine for the future coastal ocean. Sci Adv 4:eaar8195

* Richardson AD, Keenana TF, Migliavaccab M, Ryua Y, Sonnentaga O, Toomey M (2013) Climate change, phenology, and phenological control of vegetation feedbacks to the climate system. Agric For Meteorol 169:156-173

Rohde KH, Nehring D (1979) Ausgewählte Methoden zur Bestimmung von Inhaltsstoffen im Meer- und Brackwasser. Geod Geophys Veröff R IV, 27

* Rosenzweig C, Karoly D, Vicarelli M, Neofotis P and others (2008) Attributing physical and biological impacts to anthropogenic climate change. Nature 453:353-357

Salmi T, Määttä A, Anttila P, Ruoho-Airola T, Amnell T (2002) Detecting trends of annual values of atmospheric pollutants by the Mann-Kendall test and Sen's slope estimates - the Excel template application MAKESENS. Publications on Air Quality No. 31. Finnish Meteorological Institute, Helsinki. https://en.ilmatieteenlaitos.fi/ makesens 
Sarno D, Kooistra WHCF, Medlin L, Percopo I, Zingone A (2005) Diversity in the genus Skeletonema (Bacillariophyceae). II. An assessment of the taxonomy of $S$. costatum-like species with the description of four new species. J Phycol 41:151-176

Schlüter M, Kraberg A, Wiltshire KH (2012) Long-term changes in the seasonality of selected diatoms related to grazers and environmental conditions. J Sea Res 67: 91-97

Seip K (2015) Temperature, length of growth season and phytoplankton abundance in the Gulf of Maine. Mar Freshw Res 66:759-766

Sen PK (1968) Estimates of the regression coefficients based on Kendall's tau. J Am Stat Assoc 63:1379-1389

Smith LM, Whitehouse S, Oviatt CA (2010) Impacts of climate change on Narragansett Bay. Northeast Nat (Steuben) 17:77-90

Sommer U, Lengfellner K (2008) Climate change and the timing, magnitude, and composition of the phytoplankton spring bloom. Glob Chang Biol 14:1199-1208

Sommer U, Lewandowska A (2011) Climate change and the phytoplankton spring bloom: warming and overwintering zooplankton have similar effects on phytoplankton. Glob Chang Biol 17:154-162

Sommer U, Aberle N, Lengfellner K, Lewandowska A (2012a) The Baltic Sea spring phytoplankton bloom in a changing climate: an experimental approach. Mar Biol 159:2479-2490

Sommer U, Lengfellner K, Lewandowska A (2012b) Experimental induction of a coastal spring bloom early in the year by intermittent high-light episodes. Mar Ecol Prog Ser 446:61-71

Sydeman WJ, Bograd SJ (2009) Marine ecosystems, climate and phenology: introduction. Mar Ecol Prog Ser 393: 185-188

Thackeray SJ (2012) Mismatch revisited: What is trophic mismatching from the perspective of the plankton? J Plankton Res 34:1001-1010

Editorial responsibility: Antonio Bode, A Coruña, Spain
Thackeray SJ, Jones ID, Maberly SC (2008) Long-term change in the phenology of spring phytoplankton: species-specific responses to nutrient enrichment and climatic change. J Ecol 96:523-535

Tunin-Ley A, Ibañez F, Labat JP, Zingone A, Lemée R (2009) Phytoplankton biodiversity and NW Mediterranean Sea warming: changes in the dinoflagellate genus Ceratium in the 20th century. Mar Ecol Prog Ser 375:85-99

* Tuovinen N, Virtasalo JJ, Kotilainen AT (2008) Holocene diatom stratigraphy in the Archipelago Sea, northern Baltic Sea. J Paleolimnol 40:793-807

Utermöhl H (1958) Zur Vervollkommnung der quantitativen Phytoplankton-Methodik. Mitt Int Ver Theor Angew Limnol 9:1-38

*Wasmund N, Nausch G, Matthäus W (1998) Phytoplankton spring blooms in the southern Baltic Sea - spatio-temporal development and long-term trends. J Plankton Res 20:1099-1117

Wasmund N, Topp I, Schories D (2006) Optimising the storage and extraction of chlorophyll samples. Oceanologia 48:125-144

* Wasmund N, Göbel J, von Bodungen B (2008) 100-yearschanges in the phytoplankton community of Kiel Bight (Baltic Sea). J Mar Syst 73:300-322

Wasmund N, Pollehne F, Postel L, Siegel H, Zettler ML (2011) Biologische Zustandseinschätzung der Ostsee im Jahre 2010. Meereswiss Ber, Warnemünde, 85:1-87

Welschmeyer NA (1994) Fluorometric analysis of chlorophyll a in the presence of chlorophyll b and pheopigments. Limnol Oceanogr 39:1985-1992

Winder M, Berger SA, Lewandowska A, Aberle N, Lengfellner K, Sommer U, Diehl S (2012) Spring phenological responses of marine and freshwater plankton to changing temperature and light conditions. Mar Biol 159: 2491-2501

Yentsch CS, Menzel DW (1963) A method for the determination of phytoplankton chlorophyll and phaeophytin by fluorescence. Deep-Sea Res 10:221-231

Submitted: February 11, 2019; Accepted: May 16, 2019

Proofs received from author(s): July 5, 2019 